\section{The Role of Informal Leader in Community Development: Lessons from Mangrove Forest Conservation at Village of Pasar Banggi, Central Java, Indonesia}

\section{Purwowibowo $^{a}$, Soni Akhmad Nulhaqim ${ }^{b}$, Binahayati $^{\mathrm{c}}$}

a Social Welfare Department, Jember University, Indonesia 68121

b Social Welfare Department, Padjadjaran University, Bandung Indonesia 45363

c Social Welfare Department, Padjadjaran University, Bandung Indonesia 45363

Received: April o1, 2015 / Accepted: February 6, 2017

\section{Abstract}

This paper explores the pivotal and influential roles of an informal leader in community development at Pasar Banggi village, Rembang, Central Java particularly in relation to social capital, social scenarios of change, organization and local community participatory engagement in the development process. This paper, thus, presents social welfare perspective with qualitative approach by phenomenological method. As this paper was based on case studies, it deploys purposive technique to determine the key informants forwarding to next informants. Participatory observation and in-depth interviews were carried out to obtain information. The results were then analyzed through descriptive-qualitative analysis. The findings showed that the informal leader possessed natural ability in building up social capital, networks and trust in the community which revitalized socio-cultural and environmental values.

Keywords: Informal Leader (IL); Community Development (CD); Mangrove Conservation; Social Capital (SC)
Corresponding Author

E-mail: poerwowibowo@yahoo.co.id

\section{Introduction}

\subsection{Research Background}

Many studies on mangrove forest conservation have been carried out previously. However, the studies mostly covered social, ecological, and economic aspects. From the social aspect, articles with this particular issue merely discussed functions of mangrove in relation to coastal areas protection. [1]

Some countries such as Thailand, India and Indonesia included, made the most use of mangrove to buffer coastal areas against huge storm surge well-known as tsunami. This way, the countries ran mangrove forest conservation movement designed as national program supported by their respective governments. Hence, the program involved the community participation in which active cooperation of the community members played a pivotal role.

This article deals with the roles of informal leaders (IL) in building up social capital and in organizing as well as mobilizing community members through mangrove forests conservation. This apparently dealt with socio-cultural dynamics in the process of community development (CD).

The participation of community members is frequently associated with the presence of IL who is able to encourage the community participation and eventually made significant contribution to the occurrence of dynamics.

As a matter of fact, studies on roles of IL in the CD process have been regularly conducted. The studies, though, were not specific and focused merely on mangrove forests conservation some of which were conducted by: [2], [3], [4]. Moreover, the role of IL in the CD was identified as an agent of social change. Whereas [9] argues IL played a pivotal role in the development of rural communities, particularly when $\mathrm{CD}$ was related to tourism sector.

In addition, IL also served as communicators, initiators, articulators, facilitators, and mediators for $\mathrm{CD}$ in rural areas [3], [5], [6], [7], [8]. However, as IL involvement has, so far, followed the standard operational procedure initiated by the government national program (top-down approach), the IL role was merely a formality and not properly performed.

Therefore, this study highlighted the process of bottomup approach in CD. The roles of IL were actively promoted for the success of $\mathrm{CD}$ process through mangrove forests conservation.

\subsection{Problem Formulation}

The problem of the study is formulated in the following question: How are the roles of IL in the CD process? 


\subsection{Research Objectives}

This research was mainly aimed to: (a) explore the roles of IL in building up SC, organizing and mobilizing communities through active participatory efforts in mangrove forests conservation, (b) develop model of $C D$ through informal leaders' involvement.

\subsection{Research Significance}

The research was designed to provide important input to: (a) contribute theoretical concepts related to bottom-up approach concept for $\mathrm{CD}$ model through the involvement of informal leaders, (b) contribute the concept of community intervention practices by IL involvement, (c) reinforce the framework of policy makers, scientists, and social worker to involve IL through interventions setting.

\section{Literature Review}

$\mathrm{CD}$ can be referred to as 'people-centered development' [9]. In the perspective of human ecology, $\mathrm{CD}$ model was based on local contexts and resources. This model emphasizes locality in terms of creativity, knowledge, culture, resource, skill, process, and local view (bottom-up model) [10]. Thus, the level of participation of community members played a pivotal role in the whole process of $C D$ activities. In other words, the lower the community participation was, the worse process of $\mathrm{CD}$ ran [11].

Moreover, $\mathrm{CD}$ is defined as a movement designed to promote better living for the community with its ultimate goal: to increase community capacity so that the standard of life becomes better [12]. In addition, some scholar stated: " $\mathrm{CD}$ is planned efforts to produce assets to encourage residents to improve their quality of life" [13]. Thus, CD particularly focused on process by which some remarkable examples need to be provided to improve the community skills and strength by participating in the community development program [13].

$\mathrm{CD}$ is also an attempt to organize local community [14] initiated by non-governmental organization (NGO). Whereas, [15] stated that $\mathrm{CD}$ is a community capacity building in the form of a movement initiated by the community themselves to eventually build SC [16].

In the framework of $C D$ for mangrove forests conservation, participation of community members needs to be encouraged as they have close interests for their environment and mangrove forests conservation [17].

IL, in this case, can be assured to achieve the community goals in carrying out the development process. IL, regardless of their informal position and authority and due to their obviously natural leadership capacity, can inspire the community members. Thus, IL affects a successful socialization of a development program [10].

IL also played a pivotal role for the development program in rural areas [18]. The involvement of IL was influenced by SC base indicated by actions that they can make significant influence over the community.
The level of influence was affected by SC. Nevertheless, some scholars stated that rural community prefer a more paternalistic leadership type. Thus, decision-making is definitively determined by level of IL roles.

Social activities become more effective with IL command system rather than command line of formal leaders [19]. Moreover, IL roles are particularly significant in planning, participating, and implementing development activity by mobilizing local SC, and in maintaining the $\mathrm{CD}$ outcomes. For instance, IL also plays a pivotal role in a community in Himeshina Japan - a country with a more modern society. [20].

IL is desperately needed especially in the process of communication for development as they serve as stakeholders in the rural areas. For instance, IL in Banten played an important role for forest community development in buffer zone [14]. In Lebak Regency, IL has harmonious relationship with the community members [21].

Formal leaders and IL are influential figures in community. In addition, they can serve as mediators and are able to encourage cooperation among the community members [6] so that peace and harmony are well achieved.

IL roles are important and strategic in CD process as they can build SC, revitalize socio-cultural norms, and build up networks and trust. Based on the social capital, IL is able to organize and mobilize community members to make significant contributions to mangrove forests conservation and maintain its sustainability.

\section{Research Methods}

\subsection{Research Design}

This research is based on social welfare perspective with qualitative ecology approach by case studies [22]. This deals with efforts of coastal village community in mangrove forests conservation to overcome their problems of embankment to eventually improve their standards of living. Participant observation used as method of data collection in which researcher went through the community life to obtain credible information. Furthermore, researcher got some information through in-depth interviews with some informants. The description of information was conducted qualitatively through both informants' viewpoints (emic) and literature review (etic). To ensure the accuracy of the information, verification or triangulation was undertaken, either through information sources or methods of data collection. Through phenomenological method and design of case studies, researcher was able to describe the roles of IL in building up SC, organizing and mobilizing the community.

\subsection{Informants}

Informants are community members actively involved in the process of $\mathrm{CD}$. They also play a pivotal role in building social capital, organizing and mobilizing community members participation. The key informants got through 
purposive selection as they will become initiators, organizers and drivers for mangrove forests conservation. Nevertheless, other informants were selected through "snowball" method [23].

\subsection{Data Collection}

The data collected was empirical data as the researcher mingled with the community during the research mostly through in-depth interviews [24] with the key informants. In addition, Observations were made in relation to mangrove forests conservation and other activities incorporated in $\mathrm{CD}$. The results appeared in the form of field notes, thoughts, feelings, experiences, and perceptions of researchers during the research.

\subsection{Data Processing and Analysis}

Data processing and analysis was conducted simultaneously in which information was indexed and coded specifically in accordance with social phenomenon occurred during the research [23]. Further information was arranged chronologically and categorically during overall CD process. Overall information was arranged in a word-by-word transcription and regularly reviewed so that it could be completely understandable.

\section{Result and Discussions}

\subsection{General Overview of Community Development at Pasar Banggi Village}

Pasar Banggi Village is located about $7 \mathrm{~km}$ away in the eastern part of coastal area in Rembang Regency, about 120 $\mathrm{km}$ to the east of the City of Semarang. As many other coastal areas in Central Java, People's life mainly depends on ponds, coast, and marine. Particularly, mangrove forests stretching $3.5 \mathrm{~km}$ long with $65-150 \mathrm{~m} 2$ thick become the greenbelt of this area serving as natural protector of pond embankment from the onslaught of seawater that it can be used as a workplace for fish and shrimp cultivation and even salt production.

Moreover, mangrove forest can also produces a variety of natural resources that can be utilized by local communities. Therefore, mangrove forest is the pride of people of Pasar Banggi village. The coastal village with mangrove forests established through the village $C D$ is widely known among academicians, students, faculty members, researchers, government officials and the international communities to conduct a comparative study, research, and tourism.

The notion to undertake mangrove forest conservation efforts was genuinely initiated by local communities concerned. The so-called bottom-up CD first came from the person who later on became IL as s/he engaged pond embankment rehabilitation through mangrove conservation.
The CD has run over 40 (forty) years now since it was first initiated in 1964. Community participatory efforts have been endeavoured since then. Pond embankments previously neglected and damaged that it can now be used for fish and shrimp cultivation. Efforts were made by fish farmers for embankments to block seawater waves.

Previously, as a matter of fact, mangrove was believed as plant of myth; they grew on their own-only God can plant mangrove-without people any conservational efforts. Therefore, mangrove trees conservation was fairly challenging. Nevertheless, the IL extraordinary courage could make things possible. The mangrove trees were eventually able to grow and even the next years many more mangrove trees were planted followed by many other community members, and efforts for pond embankment protection eventually brought a notable success when the entire coastal region of Pasar Banggi Village was closed with mangrove forest.

Local community group concerned for mangrove forest conservation was namely 'Kelompok Tani Tambak Sidodadi Maju'. This particular group continued expanding the actions with the number of members have multiplied due to IL pivotal roles. Once the farmer group was set up, group leader who eventually became an IL was selected.

IL encouraged the group members in the mangrove conservation through group intensive activities. The more number of community members involved in mangrove trees conservation, the more likely the $\mathrm{CD}$ are able to be directed into effective actions.

The entire activities of Pasar Banggi Village Communities related to mangrove forest conservation enabled them to improve ecological and socio-cultural system. These are efforts of adaptation to construct changes and improvement for the environment to eventually support their lives [25]. In the concept of social welfare, this is the so-called CD that is community efforts to solve its own problems (self-help).

Mangrove forests protect not only community assets but also a variety of profitable natural resources. They also obviously prevent the coastal areas from tsunami beside direct benefits from natural and socio-cultural resources such as better oxygen supply, mangrove stems and fruits provision, area for fish and shrimp cultivation, etc.

\subsection{Grassroots Informal Leader in Community Development}

IL in the research are indigenous leaders. They were not admitted to existence through the process of election but through their potential capability clearly demonstrated in the society. IL are able to organize and mobilize the community full potentials in participatory actions for mangrove forests conservation.

IL work in association with local organization. The farmer group set-up was aimed at providing those concerned for mangrove-pond a forum for the exchange of views and ideas. This way, IL existence was desperately needed for coordination to encourage $C D$. 
Aside from skills (natural resource management), competencies (cross-cultural awareness and sensitivity) and values (knowledgeable, determined, engaging and optimistic), as he was a former member of Indonesian army, the IL also has vast social network both within the community members and the public at large in which he has experience in liaising and collaborating with NGO's and other external agencies to develop collaborative initiatives. In addition, he was also able to develop local wisdom as a social capital.

\subsection{The Role Informal Leader in Building Social Capital}

Each community possesses SC in the region in the form of "cultural values" and environment (norms), trust, and networking. Village of Pasar Banggi also has SC functioning as bounding, bridging and connecting [26] between the community members and IL, community and the public at large. The coastal communities have social capital in terms of social norms, the existence of ponds, coastal environment, and mangrove forest.

IL roles in $\mathrm{CD}$ are related to mangrove forest conservation in connection with efforts to build social capital. SC needs to be revitalized by IL to mobilize the community limitless potentials in $\mathrm{CD}$ activities such as firstly through coastal communities' set-up of local and environmental values. For instance, to revitalize these values, the IL created 'rhyme' or 'poem' to motivate the community members.

Secondly, SC was built up in the form of trust. Strong belief was encouraged to demolish myth remaining in the society as mangrove trees were believed that only God plant it. To build such belief, IL needed to work hard to be able to plant mangrove and build up trust of the community members.

Thirdly, SC was built up in the form of network. The network worked horizontally (micro) and vertically (macro). To promote development process reinforced with community participatory efforts, network needed to be accelerated. Even through group establishment, network was also built up.

With SC already set up in the community, IL was able to organize and mobilize community members' participatory efforts in mangrove forest conservation. Furthermore, SC can transform into the communities' vision for a better achievement [27] of mangrove forest conservation.

\subsubsection{Cultural Values Building}

\section{a. Working in groups:}

This particular type of working is apparently group-work model which has long been undertaken and has become part of Indonesian culture. In the context of mangrove forest conservation in the village of Pasar Banggi, Central Java, the group-work was encouraged from mangrove seed cultivation, mangrove tree planting, and the conservation.
Eventually, in the harvest, mangrove fruit was sold together to improve the group's better life.

\section{b. Group Gathering (Hearing)}

IL did not rule authoritatively yet voluntarily demanded group participatory efforts in determining activities to be conducted through a group-work. For instance, determination of place and time concerning mangrove seed cultivation, planting mangrove trees. In short, efforts taken in relation to mangrove conservation were initiated to be conducted in group-works. As group of pond farmers had monthly gathering (hearing) initiated by IL to talk about many things dealing with mangrove forest conservation.

Above-mentioned description is well stated by $\mathrm{Mr}$. Suryadi-the IL di Pasar Banggi:

"Mr. Suyadi (IL): people in coastal area generally have good cultural values such "Gotong Royong" as working in groups. This particular cultural value was not apparently undertaken in daily life. This was obviously seen when they repaired their ponds embankment damaged by huge storm surge. However, when I managed to plant and conserve mangrove, other pond owners voluntarily welcome to work together / work in group to plant mangroves on the embankments Moreover, mangrove tree planting was not only on their respective personal properties but also on free land in the coastal areas. With the group-work, we eventually managed to realize mangrove forest conservation in the village with 3,5 $\mathrm{km}$ long and more than 60 acre wide." (Interview held in Rembang, o5 Mei 2013).

\subsubsection{Environment Norms}

As environment has its own right to go on living. Mangrove forest conservation was not only for the betterment of human's life but also for the environment itself. Environment also needs to be developed and conserved. For this reasons, IL work professionally in cooperation with people and groups of people in the coastal areas in Central Java, village of Pasar Banggi was one of the examples.

\subsection{The Role of Informal Leader in Revitalizing Socio-Cultural and Environmental values}

SC in coastal communities deals with the coastal environment in the form of socio-cultural and environmental values. Coastal environment is considered to possess many life sources that its presence becomes important element. In addition, people who live in coastal areas in Pasar Banggi show serious concern for surrounding environment.

Unfortunately, their concerns lead to superstitious actions such as illogic respect towards big tree. They even believe that 'mangrove trees do dhikr (remembrance of God); wishing a better planting while being dashed by the wind' (24).

Based on the facts, it is obvious that harmonious relationship between community and mangrove forest develop. Thus, mutual symbiotic relation which benefit 
both parties were cultivated. Therefore, activities for a winwin strategy in relation to coastal environment and community adaptation towards life of environment need to be taken seriously.

Furthermore, religious values implemented by both IL and community members to realize mangrove forest conservation is obviously a sort of good action such as taking for a prayer before planting mangrove trees was begun.

Social norms, as a matter of fact, are connected to the presence of mangrove forests and coastal community life. When mangrove forests are destroyed, the ponds are no longer a place for cultivation. Thus, fish farmer's activities to earn for a living ruin. Therefore, mangrove forests are socioculturally part of community life in village of Pasar Banggi.

Communications through social and cultural values comprehension between IL and community members apparently encourage both parties to conserve mangrove forests. Pasar Banggi village are highly dependent on mangrove forests as they can prevent ponds from damage. Ponds are obviously main assets for people of Pasar Banggi as embankment of coastal areas.

Socio-cultural norms and environmental values are even upheld through the following expression: 'mangrove forests grow, my village is shady' [28]. The expression implies strong relationship between mangrove forests and the coastal village people, IL included.

Social and cultural values of mangrove forest existence became the powerful driving force for IL and community members to prevent mangrove forest from damages. The values could as well trigger IL and the community members to conserve mangrove forests.

Another maxim is as follows: "When ponds are fertile, the community lives prosperously" [24]. Socio-cultural and environmental values show the dependence of coastal communities on mangrove forests and ponds. Mangrove forests conservation is apparently manifestation of pond fertility. Similarly, mangrove forest fertility indicated the communities' prosperity as it protects ponds, something used by people of coastal areas to make a living.

That is why SC, IL and community members are obliged to conserve mangrove forests to ensure their fertility. Pond fertility will have impact on the community members' work that they will eventually live prosperously.

\subsection{The Role of Informal Leader in Building Trust in the Community}

Trust as another SC also worked well in Pasar Banggi Village. Trust also served as a driving force for IL and the community members to initiate mangrove forests conservation. In other words, since mutual trust between IL and communities of Pasar Banggi Village was upheld the entire movement especially the ones related to mangrove forest conservation to improve life of communities worked very well.
Efforts to build up trust were taken continuously through repeated actions of planting mangrove trees. Once failure was resulted in, IL directly made better actions by searching for knowledge of planting and conserving mangrove trees / forest.

In addition, building up trust also took place through local institution establishment such as 'Kelompok Tani Tambak Sidodadi Maju" set-up. The group was the medium to establish trust between those who share things in common. All people in the group could have mutual trust in conserving mangrove forest. Eventually, since trust was developed, tolerance and respect came in line. These features became a SC foundation to encourage mutual cooperation in all CD activities such as mangrove forest conservation.

Mr. Suryadi confirmed this in the following interview:

"Mr. Suyadi: community in the coastal area first had only a little trust in mangrove tree plantation. They maintained the myth persisting that mangrove could not be planted by human beings, Mangrove tree could grow on their own or only God can do it. To convince people living in the coastal area about mangrove tree planting / conservation, I had to give some examples. Therefore, I planted some mangrove trees on my own embankments and let them grow well despite the fact that I failed in the first 2 years. The failure reinforced the people's belief towards myth. However, I summoned my courage to even conserve mangrove forest till I achieve the success. They then built up their trust in myself and eventually believed that human beings can also plat mangrove trees. They simply needed a clear example of how mangrove trees could grow in the coastal area. They eventually planted the trees on their own embankments themselves. I finally managed to encourage them to even plant more mangrove trees together with other people in the area." (Interview held in Rembang, 1o Mei 2013)

\subsection{The Role of Informal Leader in Building up Social Network}

Another important role of IL is building up social network for the communities. Network built-up also deals with local institution set-up [30]; 'Kelompok Tani Tambak Sidodadi Maju' for instance. The local agency was established by IL in cooperation with community members to conduct implement mangrove forest conservation.

At first, the social network only had pond owners as the members. Yet, the growing number of people involved in aquaculture made these particular members move to farmer group. Recently, the pond farmer group consist not only pond owners but also fish farmers and pond workers although in pond ownership status, members of the group are bound in horizontal social networks, i.e. those with common interests such conducting joint activities (by mutual assistance) to conserve mangrove forest.

In addition, horizontal social networks tied up people with the same socio-economic status. All of mangrove care community members joining the group have the same 
background and problem: pond cultivation with embankment damage. By the horizontal social networks, they are bound socio-economically by the presence of ponds that they eventually cooperate to conserve mangrove forest.

Furthermore, vertical networks worked as well. This network connects unequal socio-economic status. The social relations worked in harmony especially among pond owners and tenants, pond owners and pond workers, tenants and pond workers. They were all tied up within the same interests that is pond management for fish cultivation.

Vertical social networks were also built up among various stakeholders such as government of village, district, regency, province, and central governments which was carried out to reinforce and accelerate process of CD.

Through vertical network, IL and community members deserved technical assistance, funding, and equipment. The regency government helped with polyback while the central government helped provide revolving funds to accelerate activities and other assistance from various stakeholders.

Network built-up enables IL to organize many activities for the communities to control CD in relation to planting, conserving mangrove trees at their respective ponds, villages and lands. By working together, sharing for mangrove forest ownership increased though it basically was not a private property but belongs to the community.

Furthermore, with various stakeholders, vertical social networks apparently support process of $C D$ particularly dealing with activities of mangrove forest conservation. The support was not only in the form technical assistance, equipment support, and financial aid, but also related to mutual cooperation for mangrove forest conservation.

Horizontal and vertical social networks enabled IL to organize community members through group activities. In the group, IL can build up internal SC along with the community members. In addition, with various stakeholders, IL can even strengthen external networks to accelerate CD activities.

Social networks played a pivotal role in sharing and exchanging knowledge, peer-learning, and equal responsibility for mangrove forest conservation. In ecological terms, mangrove forests become important assets which need to be maintained to increase the communities' prosperity. Here is an example of interview with Mr. Suryadi (IL):

"Mr. Suyadi: I suggest that the people in the coastal area should have local institution which has concern for the environment. This particular group plays a pivotal role for mangrove forest conservation. Pond owners will have better results when they work together in a group, such as 'Kelompok Tani Perikanan Sidodadi Maju'. The whole activities get better and managed to realize mangrove conservation. The local institution set-up was the first step of social network establishment related to mangrove care. The farmer group voluntarily works professionally to realize mangrove forest conservation that is eventually well-known throughout Rembang and Central Java. As the result, good cooperation between local institution, NGO and government was improved. We are well supported in the form of polyback facilities, continuous fund, group-work participation for mangrove trees planting, etc. We feel that 'Kelompok Tani' established opens social network not only better relationship among community members (pond farmer group) but also a wider networking even to central government and many NGOs. (Interview held in Rembang, 11 Juli 2013).

\subsection{The Role of Informal Leader in Organizing and Mobilizing Community Members}

Through CD process IL shared idea and vision to the community as it led to SC built-up. The sharing came in the form of social and environmental values revitalization, trust built-up and micro and macro social networks whereas through SC, IL can organize CD activities such as member coordination in which farmer group took part in mangrove forests conservation.

The role of IL in building up the community SC encouraged communities to be aware of assets value that they voluntarily participated in the activities of mangrove forest conservation.

IL valued love, humility, and altruism [30] in implementing his leadership through actions and behaviors voluntarily followed by community members to converse mangrove forest. In this case, IL acted as a social change agent. This strategic position enabled him to work harmoniously with the communities as he originally grew up in the local community.

This fact indicated that IL can be an effective social change agent in the community as he was acceptable by all community levels particularly in mangrove conservation. Through local institution [32], IL mission to organize and mobilize the communities can be eventually realized.

IL in CD process played an important role in organizing the group members and mobilizing their participatory efforts to eventually achieve the community vision. Through community group, SC in the form of trust and sense of togetherness among the community members became even stronger, and this made the social network become wider.

In organizing the community members, IL worked as organizer and played a pivotal role in mobilizing all resources that the community apparently managed to work together to solve their own problems. The success in organizing the community members fervently supported sustainability of the community capacity building in dealing with new problems. IL organize the community members to learn as well as to teach technical skills related to mangrove tree planting and other activities of $C D$ process.

IL organized not only the community members who joined pond farmer group but also all potentials of community stakeholders to work together to realize mangrove forest conservation and maintain its sustainability. The existence of ponds and other resources availability can sustain the whole community members to improve the standard of living. 


\section{Conclusion and Recommendation}

\subsection{Conclusions}

IL played a pivotal role in $\mathrm{CD}$ to build SC, that is, revitalizing socio-cultural and environmental norms, building up trust, and building up networks through local organizations establishment. Whereas, through SC IL managed to organize and mobilize the potentials of community members and stakeholders in the form of participatory efforts for mangrove forests conservation. As the community asset, mangrove forest provides a variety of natural resources in the surroundings and protects ponds to improve the communities' quality of life.

\subsection{Recommendation}

As role of IL is very important in $\mathrm{CD}$, this is an obvious example of bottom-up approach in generating community activities. In bottom-up model, all activities are initiated, implemented, and evaluated by the communities concerned for the improvement of life quality. So far, CD model, however, was designed by outsiders, community members and IL took part at further activities. This way, such a model of community and IL participatory engagement deployed top-down development model.

This particular bottom-up model can be referred to as a model of CD with local wisdom basis, local resources. So far, IL also considered as local resources in CD. In rural CD, IL played a pivotal role as social change frontline to encourage and facilitate the community.

\section{References}

[1] Sukristjoro Sukardjo. 2012. "Indonesian Mangrove: Critical Challanges and Strategies for Their Sustainable Management After the 2004 Indian Ocean tsunami”, In Sharing Lesson on Mangrove Restoration. Proceedings and a Call for Action from an MFF Regional Colloquium (Mamallapuran, India, 2012): p. 39-50.

[2] http://www.Mangrovesforthefuture.org/assets/Repository/Doc uments/Call-for-ction-and-Proceedings-from-2012-ColloquiumMamallapuram-India.pdf accessed 28 June 2013.

[3] M. Foster. 2008. "Informal Leadership in Community-Driven Development: Implications for Transformation”. ProQuest Dissertations and Theses. The Humanities and Social Sciences Collection pg. n/a.

[4] C. Washington-Ottombre. 2010. "The Role of Local Institutions in Shaping Household Responses to Climate Change and Variability: a Case Study along the Slopes of Mt. Kenya”. Purdue University Gradyate School West Lafayette, Indiana: Thesis/Dissertation Acceptance. Pro-Quest Thesis-Dissertation.

[5] D. Falmer 2011. "Insiders Voices: A Phenomelogical Study of Informal Teacher Leadership from The Perspective of Those Who Choose to Lead". ProQuest Dissertations and Theses. USA: School of Education, Indiana University of Pennsylvania.

[6] A. Patton. 2005. "Effectivelly of informal leader at local area in Malianu Region, East Kalimantan”. Jurnal Aplikasi Manajemen. Volume 3. No. 3. p.287 - 293. Samarinda: FISIP Universitas Mulawarman.
[7] S. Sulasmi. 2008. "The role informal leadership of building relationship" Surabaya: Economic Magazine. Vol. XVIII, No.1 April 2008. p.35 - 53

[8] [7] A. Rostiyati 2009. The role informal leader in Guradog Community". Research Journal of History and Cultural.Vol. 1 No.2 June 2009.

[9] Suradisastra and Priyanto. 2011. "Community empowermwent of local informal leader in Banten Region. Jurnal: Wartazoa, Vol. 21, No. 2, 2011, p. $51-59$

[10] David C. Korten 1987. "Third Generation NGO Strategies: A Key to People-Centered Development", World Development Pergamon Journals 15, p.145-159.

[11] http://www.sciencedirect.com/science/article/pii/o305750X879 01537.es Accessed 16 November 2014.

[12] Jim Ife and Frank Toresiero 2008. CommunityDevelopment. Yogyakarta: Pustaka Pelajar.

[13] Sutomo. 2011. Community Development, there is antithesis? Yogyakarta: Pustaka Pelajar.

[14] D. Brokensha and Peter Hodge. 1969. CommunityDevelopment, anInterpretation. Chicago: Chandler Publishing Company.

[15] G. P. Green and A. Haines. 2007. Asset Building and Community Development. 2nd edn. CA: Thousand Oaks, Sage.

[16] W.T. D. Groot et al., 2006. "Community Action for EnvironmentalRestoration: A Case Study on Collective Social Capitalin India" .Journal Environmental Development Sustainable. 10:519-536 DOI 10.1007/s10668-006-9078-8

[17] R. J. Chaskin. 2001. "Building Community Capacity: A Definitional Framework and Case Studies from a Comprehensive Community Initiative". Journal Urban Affairs Review. January. 2001. Vol. 36. No. 3. pp. 291-323.

[18] R. Gittell and A. Vidal. 1998. Community Organizing. Building Social Capital as a Development Strategy. USA: Sage Publication, Inc.

[19] K. Pudjianto. 2009. "Community Participation in Mangrove Forest rehabilitation”. Thesis. IPB Bogor: Agricultural University Scientific Repository.

[20]Z. A. Barlan. 2011. "The role of local informal leader in successfully rural development in Bogor Region”. Dissertation. Bogor: IPB. Faculty of Human Ecology. http://repository.ipb.ac.id/handle/123456789/51855. Accessed 17 September 2013

[21] Sudibyo. 2006. "Informal Leader Empowerment to Building Community Participation in Sustainability Tourism Development”. Tourism Journal. Vol. 11 No. 2. July 2006.

[22] C. Banyai. 2009 "Community Leadership: Development and The Evolution of Leadership in Himeshima" Juornal of eContent Management Pty Ltd Rural Society. 19:3 pp. 241-261

[23] Oekan Soekotjo Abdoellah. 1997. Understanding Adaptation of Community Trnsmigration, Anthroplogy-Ecology Approach". Prisma. No. 7 XXVI July - August pp. $51-63$.

[24]John W. Creswell. 2010. Research Design. Yogyakarta: Pustaka Pelajar.

[25] Sugiyono. 2005. Memahami Penelitian Kualitatif. Bandung: CV Alfabeta.

[26] Burhan Bungin (edt). 2001. Metodologi Penelitian Kualitatif: Aktualisasi Metodologis ke Arah Ragam Varian Kontemporer. Jakarta: Raja Grafindo.

[27] Jo Annie Schneider. 2006. Social Capital and Welfare Reform, Organization, Congregation, and Communities. New York: Columbia University Press.

[28] D. Mc.Clleland et.al, 1976. The Achievement Motive. England: Oxford Irvington.

[29] H. Suyadi 2013. In-depth interview. He is Informal leader in Pasar Banggi Village. 
[30]R. A. Cramb. 2002. "The Role of Traditional Institutions in Rural Development: Community-Based Land Tenure and Government Land Policy in Serawak, Malaysia”. Journal of World Development. Vol 18. Issue 3. pp. 347-36o.

[31] K. A. Patterson, 2003. "Servant Leadership: A Theoretical Model". Dessertation. Regend University Virginia Beach. V. A. https://regent.edu/acad/global/publications/bpcproceedings/2 oo8/selfjesusleadership.pdf . Accessed 12 November 2013

[32] Yunita T. Winarto and Ezra M. Choesin. 2001. "Strengthen of Local Genius, Building Local Organization: Management of Natural Resources" Indonesia Anthropology Journal Vol. 64, p. 91-o6.

http://anthropology.fisip.ui.ac.id/httpdocs/jurnal/2001/64/full/ ogytw64.pdf. Accessed 24 May 2013. 